\title{
PENGARUH KETAHANAN KELUARGA TERHADAP KEGEMARAN BERMAIN GAME ONLINE PADA SISWA SD DI KELURAHAN MULYOREJO
}

\author{
THE INFLUENCE OF FAMILY RESILIENCE TO A CRAZE FOR PLAYING \\ ONLINE GAMES ON STUDENTS IN KELURAHAN MULYOREJO
}

\author{
Siti Kolipah, Shrimarti Roekmini Devy \\ Departemen Promosi Kesehatan dan Ilmu Perilaku \\ Fakultas Kesehatan Masyarakat, Universitas Airlangga Surabaya \\ Email :sitikolipah1994@gmail.com
}

\begin{abstract}
The family is a small unit in a nation and its existence having influence large enough to successful the development of the power quality. Every family was expected to have the ability to exercise functions and its role in the economic aspect, social, psychology and culture. Changes in family have influence that is not good for families, so the family is undergoing many changes of form, function and role. The study is done to analyze relations endurance family to indulgence playing games online at primary school student of grade IV and V Hidayatul Ummah primary school in Mulyorejo urban village, Surabaya. Research carried out to a cross sectional by adopting quantitative. Technique data collection was carried out by the provision of the questionnaire at 62 primary school student still was played games online. The sample collection by means of simple random sampling. Variable independent to research is family resilience $(X)$ consisting of three variables namely variable their physic (X1), psychological resilience $(X 2)$ and social resilience $(X 3)$ while variable bound was a play online games $(Y)$. The result showed the significant influence of their physic family indulgence students to play online games (sig = 0,000; or =0,239). Conclusion that can be drawn is the their physic family being or good enough have leverage large enough to play online games in children. Thus, parents must continue to monitor and limit their children in playing online games and give education about the dangers of playing online games
\end{abstract}

Keywords: family resilience, students, game online

\begin{abstract}
Abstrak: Keluarga merupakan lembaga terkecil dalam suatu bangsa dan keberadaannya memiliki pengaruh yang cukup besar terhadap keberhasilan pembangunan sumberdaya yang berkualitas. Setiap keluarga diharapkan memiliki kemampuan untuk melaksanakan fungsi dan perannya dalam aspek ekonomi, sosial, psikologis dan budaya. Perubahan dalam keluarga memiliki pengaruh yang tidak baik bagi keluarga, sehingga keluarga tersebut mengalami banyak perubahan bentuk, fungsi dan peran. Penelitian ini dilakukan untuk menganalisis pengaruh ketahanan keluarga terhadap kegemaran bermain game online pada siswa sekolah dasar di kelas IV dan V SD Hidayatul Ummah Kelurahan Mulyorejo, Surabaya. Penelitian dilaksanakan dengan rancangan Cross sectional dengan menggunakan pendekatan kuantitatif. Teknik pengumpulan data dilakukan dengan pemberian kuesioner pada 62 siswa sekolah dasar yang masih gemar bermain game online. Pengambilan sampel dengan cara Simple random sampling. Variabel bebas pada penelitian adalah ketahanan keluarga (X) yang terdiri dari tiga variabel yaitu variabel ketahanan fisik (X1), ketahanan psikologis (X2) dan ketahanan sosial (X3) sedangkan variabel terikat adalah kegemaran bermain game online (Y). Hasil penelitian menunjukkan adanya pengaruh yang signifikan antara ketahanan fisik keluarga siswa terhadap kegemaran bermain game online $(\mathrm{sig}=0,000 ; \mathrm{OR}=0,239)$. Kesimpulan yang dapat ditarik adalah tingkat ketahanan fisik keluarga yang sedang atau cukup baik mempunyai pengaruh yang cukup besar untuk bermain game online pada anak. Dengan demikian, orangtua harus senantiasa mengawasi dan membatasi anaknya dalam bermain game online serta memberikan edukasi tentang bahaya bermain game online.
\end{abstract}

Kata kunci: ketahanan keluarga, game online, siswa

\section{PENDAHULUAN}

Mayoritas masyarakat Indonesia saat ini sedang mengalami masalah dalam kehidupan rumah tangga, penyebabnya adalah kurangnya nilai ketahanan dalam keluarga tersebut. Banyak ditemukan keluarga yang berujung pada kasus perceraian, dan banyak kasus tersebut yang akhirnya berdampak 
pada psikologis anak (Handayani, 2011). Ketahanan sendiri merupakan suatu upaya pencegahan dari berbagai hal dan masalah dalam kehidupan, sedangkan keluarga merupakan suatu institusi terkecil dalam suatu bangsa dan keberadaan keluarga juga sangat berpengaruh cukup besar terhadap keberhasilan pembangunan mental generasi bangsa. Adanya keluarga juga sangat berfungsi sebagai suatu unit pendidikan pertama bagi anak. Hal tersebut agar berkualitas dan guna peningkatan kesejahteraan dalam keluarga, pendidikan pertama yang diberikan di dalam keluarga adalah memberikan dasar-dasar kepribadian seperti nilai kejujuran, solidaritas, kecerdasan, kerjasama, saling menghargai, kepercayaan serta bersikap positif antar sesama anggota keluarga.

Ketahanan keluarga yang lemah dan buruk akan menjadikan keluarga tersebut rentan dan mudah mengalami berbagai masalah krisis seperti halnya keretakan dalam rumah tangga, diskriminasi, kurangnya komunikasi antar anggota keluarga, kurangnya rasa menghargai dan memiliki, eksploitasi bahkan sampai ada kasus pembunuhan dalam keluarga (Puspitawati, 2013). Adanya fakta yang membuktikan bahwa apabila dalam keluarga tersebut tingkat ketahanan keluarganya lemah dan mengalami berbagai permasalahan, maka anak yang merasakan dampaknya. Seorang anak yang menjadi korban dari tingkat ketahanan keluarga yang lemah dan buruk akan mengalami berbagai hambatan seperti halnya: hambatan tumbuh kembang, hambatan kurangnya rasa dimiliki dan dicintai, kurang diperhatikan keberadaannya sehingga anak tersebut lari dari rasa bosan dan penat dari permasalahan tersebut. Dalam mencari kesenangan dan mencari pelampiasan dari berbagai masalah, pada umumnya anak-anak lebih suka bermain atau game. Permainan bagi anak memang sangat penting untuk memacu perkembangan baik fisik, emosi, mental, kreativitas serta sosial (Soetjiningsih, 1998).

Seiring perkembangan teknologi yang begitu maju dan pesat, permainan juga mengalami perkembangan dan kemajuan, namun seiring kemajuan zaman permainan zaman dahulu sekarang sulit ditemukan di kota besar seperti di Surabaya. Sebab sudah tersisih adanya game online, yang dengan mudah untuk dimainkan hanya saja perlu adanya sarana pendukung yaitu komputer/ laptop dan layanan internet (Sanditaria, 2008).

Di Indonesia game online sudah cukup banyak peminatnya, bahkan menurut Biro Pusat Statistik (BPS) tahun 2014 mengenai data presentasi pengguna game online di Indonesia, total besaran nilai pasar dari industri sudah mencapai 400 juta rupiah per tahunnya. Sebagian besar industri game online di Indonesia dimiliki oleh Publisher dari negara luar seperti halnya: Amerika, Singapore, Korea, China dan sebagainya. Sampai saat ini tercatat ada sekitar 248 judul game online yang masih dipublikasikan di Indonesia. Namun pada tahun 2015 hanya ada 93 judul yang masih aktif dan diminati oleh para pemain. Pada setiap tahunnya para pemain game online mengalami peningkatan sebesar $5-10 \%$ seiring dengan semakin pesatnya perkembangan teknologi dan pengguna internet.

Game itu sendiri merupakan aktivitas yang dilakukan untuk hiburan atau kegiatan menyenangkan yang memiliki aturan sehingga ada yang menang dan kalah (Angela, 2013). Game online merupakan game yang berbasis elektronik dan visual, yang biasanya menyebabkan beberapa timbulnya penyakit karena adanya efek kecanduan dalam melakukan permainan ini. Untuk mengakses sarana game online sekarang ini sangat dimudahkan, karena sudah banyak warung internet (warnet) yang menyediakan dan memfasilitasi adanya game online selama 24 jam, sehingga mereka yang kecanduan akan permainan tersebut dengan leluasa dapat menggunakannya. Berdasarkan hasil observasi (Senin, 11 Desember 2015), ditemukan warung internet sekarang ini sudah tidak asing dan mudah dijangkau dikalangan siswa sekolah di desa dan kelurahan, bahkan ada lebih dari satu di satu kelurahan. Adanya permainan game online juga dapat menimbulkan dampak positif dan negatif, dampak positif yang ditimbulkan antara lain: dapat menambah banyak teman, dapat menguasai komputer, menghasilkan banyak uang serta dapat menghibur diri. 
Dampak negatif yang ditimbulkan antara lain: menghamburkan uang, membuat kecanduan, membuat lupa waktu untuk kegiatan yang lebih bermanfaat seperti lupa belajar, makan, bahkan lupa untuk ibadah serta menjadikan anak berbohong kepada orangtuanya karena pada awalnya berpamitan untuk sekolah ternyata dia bolos sekolah untuk bermain game online (Rikiyanto, 2011).

Beberapa anak usia sekolah dasar yang mengungkapkan keluhan setelah terpapar dengan game online, yaitu: mengeluhkan sakit pada tulang belakang, nyeri pada jari tangannya, dan ada beberapa anak juga yang mengalami stres. Karena dalam bermain game online anak tersebut kalah dalam permainan, serta banyak anak yang lupa mengerjakan pekerjaan rumah (PR), lupa ibadah karena terlalu asyik dengan bermain game online.

Setelah melakukan observasi awal selama lima hari di warung internet wilayah Kelurahan Mulyorejo, Kecamatan Mulyorejo, Kota Surabaya. Mulai hari Senin tanggal 11-15 Desember 2015, ditemukan bahwa setiap harinya warnet tersebut dipenuhi oleh siswa sekolah dasar untuk bermain game online. Biasanya mereka bermain setelah pulang sekolah pada pukul 12 siang dan malam hari pada pukul 19.00. Dari observasi tersebut ditemukan ada sekitar lima warung internet yang memfasilitasi game online selama 24 jam. Dalam sekali bermain siswa tersebut membayar sebesar Rp. 3000-5000 per jam. Dalam satu warung internet biasanya dipenuhi sekitar 6-10 siswa sekolah dasar untuk bermain.

Berdasarkan dari permasalahan tersebut, penelitian ini menuliskan artikel ilmiah tentang bagaimana pengaruh ketahanan keluarga terhadap kegemaran bermain game online pada siswa kelas IV dan V di SD Hidayatul Ummah Kelurahan Mulyorejo, Surabaya. Alasan pemilihan lokasi karena keadaan lingkungan di sekitar SD tersebut banyak siswa yang bermain game online.

\section{METODE}

Penelitian ini menggunakan jenis penelitian kuantitatif dengan tujuan untuk menganalisis ada tidaknya pengaruh antara variabel $\mathrm{X}$ dan variabel $\mathrm{Y}$. Penelitian ini menggunakan design penelitian observasional analitik, Pendekatan penelitian menggunakan studi Cross sectional. Lokasi penelitian dilakukan di SD Hidayatul Ummah, Kelurahan Mulyorejo, Surabaya. Jumlah populasi dalam penelitian yaitu sejumlah 72 siswa.

Pengambilan sampel penelitian ini menggunakan teknik simple random sampling. Sehingga didapatkan besar sampel dalam penelitian ini sejumlah 62 siswa yang masih gemar bermain game online dan usia 10-11 tahun. Cara penentuan sampel pada penelitian ini sesuai dengan kriteria inklusi. Kriteria inklusi pada penelitian ini adalah: responden gemar bermain game online, kelas IV dan V (dengan usia 10-11 tahun) dan sekolah di SD Hidayatul Ummah, Kelurahan Mulyorejo, Surabaya. Instrumen pengumpulan data dalam penelitian ini melalui kuesioner berupa pertanyaan terstruktur yang diisi sendiri oleh responden. Instrumen pengumpulan data menggunakan skala Likert yang mempunyai gradasi positif dan negatif dengan kriteria skor: Sangat setuju dengan skor 4, Setuju dengan skor 3, Tidak setuju dengan skor 2 dan Sangat tidak setuju dengan skor 1.

Analisis data dalam penelitian dilakukan dengan perhitungan statistik untuk melihat adanya pengaruh ketahanan keluarga terhadap kegemaran bermain game online dengan menggunakan uji regresi logistik berganda. Variabel independent dalam artikel ilmiah ini adalah ketahanan keluarga yang terdiri dari tiga indikator yaitu: ketahanan fisik, ketahanan psikologis dan ketahanan sosial. Pembuatan kuesioner tentang ketahanan keluarga mengadopsi dari buku (Sunarti, 2003).

Analisis data untuk variabel ketahanan keluarga, awalnya responden mengisi kuesioner dengan mencentang jawaban pernyataan yang dianggap sesuai pilihannya. Kemudian dari pilihan jawaban tersebut, dihitung sesuai hasil pembobotan. Sedangkan, untuk variabel dependent yaitu kegemaran bermain game online, yang dibagi menjadi tiga indikator yaitu: frekuensi bermain, lamanya bermain dan kapan waktu bermain (Indahtiningrum, 
2013). Kemudian responden memilih satu jawaban yang dianggap sebagai pilihannya, selanjutnya jawaban tersebut dikategorikan menjadi dua yaitu kecanduan dan tidak kecanduan.

\section{HASIL PENELITIAN}

Sekolah Dasar Hidayatul Ummah merupakan salah satu sekolah dasar yang berbasis informal atau disebut sekolah diniyah (Pendidikan yang di lembagakan dengan tujuan untuk mempersiapkan peserta didik dalam penguasan terhadap pengetahuan agama Islam). Namun, sekolah ini tetap berpatokan pada kurikulum seperti sekolah pada umumnya. Sekolah Dasar Hidayatul Ummah berlokasi di Jl. Mulyorejo, No 78-92, Kelurahan Mulyorejo, Kecamatan Mulyorejo, Kota Surabaya.

Sekolah ini diakui oleh pihak Dinas Pendidikan pada tahun 1976, sekolah ini juga sudah berakreditasi A, status sekolah ini adalah sekolah swasta dan kegiatan belajar mengajar dilaksanakan mulai pagi sampai sore karena ruang kelasnya bergantian. Segala fasilitas dan sarana prasarana di sekolah ini dibantu oleh Yayasan Ma'arif Hidayatul Ummah, namun sekolah ini tetap bersedia menerima bantuan dari Pemerintah seperti Dana BOS dan bantuan lainnya. Di sekolah ini tidak hanya menyediakan sekolah bagi anak sekolah jenjang sekolah dasar saja, melainkan pendidikan sekolah untuk siswa SMP dan SMA juga disediakan. Namun, untuk pendidikan SMA bangunan gedungnya tidak menyatu dengan bangunan gedung sekolah jenjang SD dan SMP.

Karakteristik responden dalam penelitian ini meliputi alamat, umur, kelas dan jumlah uang saku. Berdasarkan tabel 1 dapat diketahui bahwa mayoritas responden beralamat di Kelurahan Mulyorejo sejumlah 35 siswa atau sebesar $56,4 \%$ sedangkan minoritas responden tinggal di Kelurahan Kalikepiting sejumlah 1 siswa atau sebesar $1,6 \%$. Mayoritas umur responden yaitu 10 tahun sejumlah 32 siswa atau sebesar $51,6 \%$ sedangkan minoritas responden berumur 11 tahun sejumlah 30 siswa atau sebesar $48,4 \%$.

Mayoritas responden adalah kelas IV B sejumlah 18 siswa atau sebesar $29 \%$ sedangkan minoritas responden adalah kelas V B sejumlah 11 siswa atau sebesar 17,7\%. Hal ini sesuai dengan data sekunder yang didapat dari data sekolah SD Hidayatul Ummah dan hasil observasi pada hari Senin, 11 Desember 2015.

Mayoritas jumlah uang saku responden setiap harinya adalah Rp. 5.000 per hari sejumlah 25 siswa atau sebesar $40 \%$ sedangkan minoritas jumlah uang saku responden setiap harinya yaitu Rp. 8.000 sejumlah 1 siswa atau sebesar $1,6 \%$. Hal ini berarti siswa yang memiliki jumlah uang saku yang berlebih dan berpeluang untuk dapat mengakses untuk bermain game online di warung internet. Pihak sekolah dan orangtua harus senatiasa melakukan pengawasan kepada anaknya agar tidak terlalu sering bermain game online dan pihak sekolah juga lebih memberikan penambahan kegiatan ekstrakulikuler

Tabel 1. Distribusi Karakteristik Responden SD HidayatulUmmah, Kelurahan Mulyorejo,Kecamatan Mulyorejo, Kota Surabaya Tahun 2016.

\begin{tabular}{lcc}
\hline Karakteristik Responden & f & $\mathbf{\%}$ \\
\hline Kelurahan & & \\
Mulyorejo & 35 & $56,4 \%$ \\
Dukuh Sutorejo & 5 & $8 \%$ \\
Kalijudan & 12 & $19,3 \%$ \\
Mojoklangru Lor & 4 & $6,4 \%$ \\
Kedung Tarukan & 2 & $3,2 \%$ \\
Kalikepiting & 1 & $1,6 \%$ \\
Kalisari & 3 & $4,8 \%$ \\
Umur & & \\
10 tahun & 32 & $51,6 \%$ \\
11 tahun & 30 & $48,4 \%$ \\
Kelas & & \\
Kelas IV A & 16 & $25,8 \%$ \\
Kelas IV B & 18 & $29 \%$ \\
Kelas V A & 17 & $27,41 \%$ \\
Kelas V B & 11 & $17,7 \%$ \\
Jumlah Uang Saku per hari & \\
Rp. 2.000 & 4 & $6,4 \%$ \\
Rp. 3.000 & 4 & $6,4 \%$ \\
Rp. 4.000 & 12 & $19,3 \%$ \\
Rp. 5.000 & 25 & $40 \%$ \\
Rp. 6.000 & 3 & $4,8 \%$ \\
Rp. 7.000 & 7 & $11,2 \%$ \\
Rp. 8.000 & 1 & $1,6 \%$ \\
Rp. 10.000 & 6 & $9,6 \%$ \\
\hline & &
\end{tabular}


pada siswa agar mereka menghabiskan waktu dengan kegiatan yang positif serta pemberian edukasi dan informasi tentang bahaya bermain game online. Berikut adalah tabel 1 distribusi karakteristik responden:

Ketahanan keluarga merupakan kemampuan keluarga dalam mengelola sumberdaya dan masalah yang dihadapinya, dengan tujuan untuk memenuhi kebutuhan keluarganya serta menyelesaikan segala macam permasalahan yang dihadapi dalam keluarga tersebut. Dalam ketahanan keluarga terdiri dari tiga indikator antara lain: ketahanan fisik, ketahanan psikologis dan ketahanan sosial (Sunarti, 2001). Berdasarkan data primer tentang ketahanan keluarga siswa kelas IV dan V di SD Hidayatul Ummah tahun 2016, diperoleh data sebagai berikut:

Berdasarkan tabel 2 didapatkan bahwa data tentang ketahanan keluarga siswa tersebut didapat melalui perhitungan hasil kuesioner yang telah diisi oleh responden. Kuesioner tersebut bersumber dari penelitian (Sunarti, 2001) dalam bukunya menjelaskan bahwa indikator tingkat ketahanan keluarga dilihat dari tiga indikator yaitu: ketahanan fisik, ketahanan psikologis dan ketahanan sosial keluarga. Pada setiap indikator ketahanan penelitian ini memberikan 5 pernyataan. Dalam menganalisis hasil kuesioner pada variabel ketahanan keluarga, penelitian ini mengklasifikan skor menjadi

Tabel 2. Distribusi RespondenBerdasarkan KetahananKeluarga Siswa Kelas IV dan Vdi SD Hidayatul UmmahKelurahan Mulyorejo Tahun 2016.

\begin{tabular}{lcc}
\hline \multicolumn{1}{c}{ Ketahanan Keluarga } & $\mathbf{f}$ & $\mathbf{\%}$ \\
\hline Ketahanan Fisik & & \\
$\quad$ Kuat & 28 & 45,16 \\
$\quad$ Sedang & 34 & 54,84 \\
Ketahanan Psikologis & & \\
$\quad$ Kuat & 24 & 38,7 \\
$\quad$ Sedang & 38 & 61,29 \\
Ketahanan Sosial & & \\
$\quad$ Kuat & 15 & 24,19 \\
$\quad$ Sedang & 40 & 64,51 \\
$\quad$ Lemah & 7 & 11,29 \\
\hline
\end{tabular}

3 tingkatan yaitu: kuat ( $80-100 \%)$, sedang $(60-<80 \%)$ dan lemah $(<60 \%)$.

Hasilnya didapat mayoritas tingkat ketahanan fisik keluarga dalam kategori sedang yaitu sejumlah 34 responden atau sebesar $54,84 \%$. Ini berarti dari tingkat ketahanan fisik keluarga sedang berarti dalam keluarga tersebut cukup mampu dalam menangani berbagai permasalahan seperti halnya masalah kebutuhan fisik keluarga antara lain: cukup mampu memenuhi kebutuhan fisik keluarga (sandang, pangan dan papan), tingkat ekonomi keluarga juga cukup baik, dan kualitas SDM juga cukup baik. Namun, minoritas responden tingkat ketahanan fisik keluarganya dalam kategori kuat yaitu sejumlah 28 responden atau sebesar $45,16 \%$ berarti dalam keluarga tersebut mampu dengan baik dalam menangani berbagai permasalahan yang dihadapi.

Selanjutnya, berdasarkan hasil penelitian didapatkan bahwa sebagian besar responden tingkat ketahanan psikologis keluarganya dalam kategori sedang yaitu sejumlah 38 responden atau sebesar $61,29 \%$. Ini berarti dari tingkat ketahanan psikologis keluarga sedang berarti keluarga tersebut cukup mampu dalam menangani atau menanggulangi berbagai permasalahan psikologis dalam keluarga, seperti halnya: cukup mampu mengendalikan emosi antar anggota keluarga, cukup mampu menjalankan dan mengajarkan nilai religius kepada semua anggota keluarga serta cukup mampu menjaga rasa saling pengertian antar anggota keluarga. Namun, minoritas responden tingkat pertahanan psikologis keluarga dalam kategori kuat yaitu sejumlah 24 responden atau sebesar 38,7\% ini berarti dalam keluarga tersebut mampu dengan baik dalam menangani atau menanggulangi berbagai permasalahan psikologis dalam keluarganya.

Hasil penelitian yang didapatkan bahwa sebagian besar responden tingkat ketahanan sosial keluarganya dalam kategori sedang, yaitu sejumlah 40 responden atau sebesar $64,51 \%$. Ini berarti dalam keluarga tersebut cukup mampu dalam menangani atau menanggulangi berbagai permasalahan sosial dalam keluarga. Seperti halnya: cukup mampu menjaga komunikasi secara efektif 
dengan seluruh anggota keluarga, cukup mampu membina hubungan sosial dengan baik antar anggota keluarga serta cukup mampu menghormati dan menghargai segala pendapat anggota keluarga. Minoritas responden tingkat ketahanan sosial keluarganya dalam kategori lemah yaitu sejumlah 7 responden atau sebesar $11,29 \%$, ini berarti dalam keluarga tersebut kurang mampu dalam menangani permasalahan psikologis dalam keluarganya.

Pada variabel kegemaran bermain game online dibagi menjadi tiga indikator untuk mengetahui tingkat kegemaran bermain responden antara lain dilihat dari frekuensi bermain, waktu bermain dan durasi bermain game online.

Berdasarkan tabel 3 menunjukkan bahwa mayoritas responden frekuensi bermain game online 1-2 kali per minggu yaitu sejumlah 28 siswa (45,16\%), dan yang frekuensi bermain game online 3-4 kali per minggu yaitu sejumlah 23 siswa (37\%), sedangkan yang frekuensi bermain game online 5-6 kali per minggu yaitu sejumlah 11 siswa $(17,74 \%)$. Hal ini sesuai data primer yang dilakukan dengan memberikan kuesioner pada responden.

Tabel 3. Distribusi RespondenBerdasarkan Kegemara BermainGame Online Siswa Kelas IVdan V di SD Hidayatul UmmahKelurahan Mulyorejo, Surabaya.

\begin{tabular}{ccc}
\hline $\begin{array}{c}\text { Kegemaran Bermain } \\
\text { Game online }\end{array}$ & f & $\mathbf{\%}$ \\
\hline $\begin{array}{c}\text { Frekuensi Bermain } \\
\text { 1-2 kali per minggu }\end{array}$ & 28 & $45,16 \%$ \\
3-4 kali per minggu & 23 & $37 \%$ \\
5-6 kali per minggu & 11 & $17,74 \%$ \\
Waktu Bermain & & \\
Pulang sekolah & 12 & $19,3 \%$ \\
Malam hari & 8 & $12,9 \%$ \\
Liburan sekolah & 30 & $48,3 \%$ \\
Setiap hari & 12 & $19,3 \%$ \\
Durasi Bermain & & \\
1-2 jam & 35 & $56,4 \%$ \\
3-4 jam & 18 & $29 \%$ \\
$>4-5$ jam & 9 & $14,5 \%$ \\
\hline
\end{tabular}

Tabel 4. Distribusi Responden Berdasarkan Siswa Kecanduan dan Tidak Kecanduan

\begin{tabular}{lcc}
\hline \multirow{2}{*}{$\begin{array}{c}\text { Ketahanan } \\
\text { Keluarga }\end{array}$} & \multicolumn{2}{c}{ Kegemaran Bermain Game } \\
\cline { 2 - 3 } & Kecanduan & $\begin{array}{c}\text { Tidak } \\
\text { Kecanduan }\end{array}$ \\
\hline Ketahanan Fisik & \\
Kuat & $6(22,2 \%)$ & $21(77,8 \%)$ \\
Sedang & $28(80,0 \%)$ & $7(20,0 \%)$ \\
Ketahanan Psikologis & \\
Kuat & $7(28,0)$ & $18(28,0)$ \\
Sedang & $22(73,0)$ & $10(27,0)$ \\
Ketahanan Sosial & \\
Kuat & $1(6,7 \%)$ & $14(93,3 \%)$ \\
Sedang & $31(77,5 \%)$ & $9(22,5 \%)$ \\
Lemah & $2(28,6)$ & $5(71,4 \%)$ \\
\hline
\end{tabular}

Mayoritas responden waktu bermain game online saat pulang sekolah yaitu sejumlah 12 siswa $(19,3 \%)$, dan yang waktu bermain game online saat malam hari yaitu sejumlah 8 siswa (12,9\%), yang waktu bermain game online saat liburan sekolah yaitu sejumlah 30 siswa (48,3\%), sedangkan responden yang waktu bermain game online setiap hari yaitu sejumlah 12 siswa $(19,3 \%)$.

Mayoritas responden durasi bermain game online 1-2 jam per hari yaitu sejumlah 35 siswa (56,4\%), dan yang durasi bermain game online 3-4 jam per hari yaitu sejumlah 18 siswa (29\%), sedangkan yang durasi bermain game online $>4-5$ jam per hari yaitu sejumlah 9 siswa $(14,5 \%)$.

\section{Hasil Analisa Pengaruh Ketahanan Keluarga dengan Kegemaran Bermain Game Online}

Uji regresi logistik digunakan untuk menganalisa pengaruh variabel ketahanan keluarga terhadap kegemaran bermain game online pada kelas IV dan V di SD Hidayatul Ummah. Populasi dalam penelitian ini adalah siswa kelas IV dan V di SD Hidayatul Ummah, Kelurahan Mulyorejo, Kota Surabaya. Dikatakan variabel itu berpengaruh, apabila nilai $(\mathrm{p}<\alpha)$ sedangkan dikatakan variabel itu 
Tabel 5. Hasil Uji Regresi LogistikBivariat Berdasarkan Variabel Dependent dengan VariabelIndependent

\begin{tabular}{lcc}
\hline \multicolumn{1}{c}{$\begin{array}{c}\text { Variabel } \\
\text { Independen }\end{array}$} & Sig & Keterangan \\
\hline $\begin{array}{l}\text { Ketahanan } \\
\text { Fisik Keluarga } \\
\text { Ketahanan } \\
\text { Psikologis }\end{array}$ & 0,000 & Berpengaruh \\
$\begin{array}{l}\text { Keluarga } \\
\text { Ketahanan }\end{array}$ & 0,216 & Tidak Berpengaruh \\
$\begin{array}{l}\text { Sosial } \\
\text { Keluarga }\end{array}$ & 0.009 & Berpengaruh \\
\hline
\end{tabular}

tidak berpengaruh jika nilai $(p>\alpha)$. Setelah data didapat dan kemudian dianalisis, maka variabel ketahanan keluarga yang terdiri dari tiga indikator: ketahanan fisik, ketahanan psikologis dan ketahanan sosial. Didapatkan bahwa indikator yang berpengaruh pada adalah indikator ketahanan fisik dan ketahanan sosial. Hasil Uji regresi logistik bivariat tersebut dapat dilihat pada tabel 5 , yaitu sebagai berikut:

Berdasarkan tabel 5 menunjukkan bahwa terdapat pengaruh antara varibel ketahanan fisik keluarga terhadap kegemaran bermain game online $(\mathrm{p}=0,000)$, dan terdapat pengaruh antara variabel ketahanan sosial keluarga terhadap kegemaran bermain game online $(\mathrm{p}=0,009)$, namun tidak terdapat pengaruh antara variabel ketahanan psikologis keluarga terhadap kegemaran bermain game online $(\mathrm{p}=0,216)$.

Berdasarkan tabel 5 menunjukkan bahwa ada pengaruh antara ketahanan fisik keluarga dan ketahanan sosial keluarga terhadap kegemaran bermain game online. Pembacaan hasil Odds Ratio (OR) pada masing-masing variabel independent dapat dilihat pada Tabel 5 .

ketahanan fisik keluarga, hasil analisis regresi logistik berganda didapatkan bahwa nilai signifikan sebesar 0,000 . Dapat disimpulkan bahwa tingkat ketahanan fisik keluarga dalam kategori sedang memiliki risiko 0,049 kali untuk gemar bermain game online dari pada ketahanan fisik keluarga dalam kategori kuat.

Dan ketahanan psikologis keluarga, hasil analisis regresi logistik berganda didapatkan bahwa nilai signifikan sebesar 0,216. Dapat disimpulkan bahwa ketahanan psikologis keluarga dalam kategori sedang memiliki risiko 0,523 kali untuk gemar bermain game online dari pada ketahanan psikologi keluarga dalam kategori kuat. Selajutnya, ketahanan sosial keluarga, hasil analisis regresi logistik berganda didapatkan bahwa nilai signifikan sebesar 0,009. Dapat disimpulkan bahwa ketahanan sosial keluarga dalam kategori sedang memiliki risiko atau kecenderungan 0,239 kali untuk gemar bermain game online dari pada ketahanan sosial keluarga dalam kategori kuat.

Dapat disimpulkan bahwa ketahanan fisik keluarga merupakan variabel yang paling berpengaruh terhadap kegemaran bermain game online pada siswa kelas IV dan V di SD Hidayatul Ummah, Kelurahan Mulyorejo, Surabaya.

\section{PEMBAHASAN}

Karakteristik responden dalam penelitian ini dibagi menjadi beberapa indikator meliputi alamat, umur, kelas dan jumlah uang saku. Variabel lain yang akan diteliti diantaranya variabel ketahanan keluarga meliputi (ketahanan fisik, ketahanan psikologis dan ketahanan sosial) dan variabel kegemaran bermain game online yang dibagi menjadi beberapa indikator diantaranya frekuensi bermain, waktu bermain, durasi bermain. Pada penelitian ini, terdapat 62 siswa yang menjadi responden.

Mayoritas responden beralamat di Kelurahan Mulyorejo, Surabaya. Hal ini sesuai dengan hasil observasi pada hari Senin, 11 Desember 2015, didapatkan bahwa di Kelurahan Mulyorejo terdapat warung internet (warnet) sejumlah 4-5. Dilengkapi dengan fasilitas game online selama 24 jam, sehingga dapat mempermudah siswa yang beralamat di Kelurahan Mulyorejo tersebut mudah untuk mengakses game online di warung internet tersebut.

Mayoritas umur responden dalam penelitian ini adalah umur 10-11 tahun dan berjenis kelamin laki-laki. pada usia 10-11 tahun. Menurut Nikita (2001), menjelaskan bahwa pada usia tersebut sebagian besar anak lebih menyukai aktivitas bermain, karena bermain merupakan aktivitas atau 
suatu dorongan dan timbulnya rasa ingin menang. Bermain menurutnya merupakan suatu kebutuhan sekunder yang sebaiknya harus terpenuhi karena dapat memberikan kesegaran baik secara fisik maupun psikis, sehingga terlepas dari segala rasa bosan, penat dan lelah serta memperoleh semangat dan energi yang baru setelah bermain. Hal ini sesuai dengan hasil penelitian Imanuel (2009), menjelaskan bahwa sebagian besar anak laki-laki lebih memilih dan menyukai bermain game online karena pada game tersebut memiliki banyak variasi bermain dengan tingkat kesulitan dan adanya unsur kekerasan serta memiliki jaringan yang permainannya dapat dimainkan secara bersama-sama walaupun tempatnya berbeda. Meskipun aktivitas bermain memang sangat penting bagi sebagian anak, tetapi saat bermain harus tetap harus pandai mengatur waktu yang tepat untuk bermain dan mana waktu yang tidak tepat untuk bermain. Karena kegiatan bermain tersebut dapat menganggu kegiatan belajar mengajar di sekolah maupun kegiatan wajib di rumah seperti ibadah, belajar, makan dan membantu orangtua (Lumban, 2013).

Mayoritas responden berada di kelas IV $\mathrm{B}$, hal ini sesuai dengan data sekunder didapat dari data sekolah SD Hidayatul Ummah, Keluruhan Mulyorejo, Surabaya dan hasil observasi pada hari Senin, 11 Desember 2015. Dalam penelitian tersebut, sebenarnya tidak ada perbedaan terkait pengambilan sampel di kelas, namun di SD tersebut didapati kurangnya ruangan kelas sehingga jadwal masuk sekolah tersebut di bagi dua shift yaitu pagi dan siang hari karena keterbatasan ruang kelas adanya perbedaan jam masuk sekolah. Aturan beda shift ini untuk kelas IV dan V, sehingga peneliti harus bergantian dalam pengambilan sampel.

Mayoritas responden jumlah uang saku per hari adalah Rp. 5.000, hal ini sesuai dengan data primer yang didapat, bahwa siswa yang memiliki jumlah uang saku yang berlebih berpeluang atau cenderung untuk dapat mengakses dan bermain game online di warung internet (warnet). Sehingga pihak sekolah dan orangtua harus senantiasa melakukan pengawasan kepada anaknya agar tidak terlalu sering bermain game online.
Ketahanan Keluarga merupakan Ketahanan keluarga merupakan kemampuan keluarga dalam mengelola sumberdaya dan masalah yang dihadapinya, dengan tujuan untuk memenuhi kebutuhan keluarganya serta menyelesaikan segala macam permasalahan yang dihadapi dalam keluarga tersebut. Dalam ketahanan keluarga terdiri dari tiga indikator antara lain: ketahanan fisik, ketahanan psikologis dan ketahanan sosial (Sunarti, 2001).

Mayoritas keluarga responden memiliki tingkat ketahanan fisik yang sedang. Maksudnya tingkat ketahanan fisik pada keluarga responden berarti dikatakan cukup mampu dalam menangani berbagai permasalahan. Seperti halnya masalah kebutuhan fisik keluarga antara lain: cukup mampu memenuhi kebutuhan fisik keluarga, tingkat ekonomi keluarga juga cukup memenuhi semua anggota keluarga, dan kualitas SDM juga cukup baik. Tingkat ketahanan fisik keluarga responden kuat maksudnya tingkat ketahanan fisiknya adalah baik, Menurut Sunarti (2003), dalam Perumusan Ukuran Ketahanan Keluarga menjelaskan bahwa semakin baik tingkat ketahanan fisik dalam keluarga, maka semakin rendah pula permasalahan fisik keluarga, semakin rendah pula penanggulangan masalah fisik keluarga dan semakin sejahtera keluarga tersebut. Namun, sebaliknya apabila ada keluarga responden yang tingkat ketahanan fisik keluarganya lemah, maka ketahanan fisik dalam keluarga tersebut masih belum dapat ditanggulangi permasalahannya sehingga menjadikan keluarga tersebut kesulitan memenuhi kebutuhan keluarganya dan kurang sejahtera serta banyak timbul perselisihan antar anggota keluarga yang menganggap segala kebutuhan fisiknya tidak tercukupi (Handayani, 2011).

Mayoritas responden tingkat ketahanan psikologis keluarga responden sedang. Dalam keluarga tersebut tingkat ketahanan psikologisnya adalah cukup mampu dalam menangani atau menanggulangi berbagai permasalahan psikologis dalam keluarga meliputi: cukup mampu mengendalikan emosi antar anggota keluarga, cukup mampu menjalankan dan mengajarkan nilai religius kepada semua anggota keluarganya 
dan serta cukup mampu menjaga rasa saling pengertian antar anggota keluarga. Menurut Sunarti (2003) dalam Perumusan Ukuran Ketahanan Keluarga menjelaskan bahwa semakin baik tingkat ketahanan psikologis dalam keluarga, maka semakin rendah pula permasalahan psikologis yang dialami keluarga, dan semakin rendah pula penanggulangan masalah psikologis keluarga dan semakin tenang dan damai keluarga tersebut. Namun, sebaliknya apabila ada keluarga responden yang tingkat ketahanan psikologis keluarganya lemah, maka ketahanan psikologis dalam keluarga tersebut masih belum mampu ditanggulangi permasalahannya sehingga menjadikan keluarga tersebut tidak harmonis dan sering terjadi perselisihan serta banyak timbul saling dendam antar anggota keluarganya (Sunarti 2003). Selain itu, dikatakan tingkat ketahanan psikologis dalam keluarga baik apabila keluarga mampu menanggulangi masalah non fisik, pengendalian emosi secara positif, konsep diri positif (termasuk terhadap harapan dan kepuasan) dan kepedulian orangtua kepada seluruh anggota keluarga (Puspitawati, 2013).

Mayoritas responden tingkat ketahanan sosial dalam keluarganya sedang, berarti dalam keluarga tersebut cukup mampu dalam menangani atau menanggulangi berbagai permasalahan hubungan sosial dalam keluarga. Seperti halnya: cukup mampu menjaga komunikasi secara efektif dengan seluruh anggota keluarga, cukup mampu membina hubungan sosial dengan baik antara anggota keluarga serta cukup mampu menghormati dan menghargai segala pendapat anggota keluarga. Menurut Sunarti (2003), dalam merumuskan Ukuran Ketahanan Keluarga menjelaskan bahwa semakin baik tingkat ketahanan sosial dalam keluarga, maka semakin rendah pula permasalahan sosial yang dialami keluarga, dan semakin rendah pula penanggulangan masalah sosial keluarga dan semakin harmonis dan adanya perhatian pada tiap anggota keluarga tersebut.

Namun, apabila ada keluarga responden yang tingkat ketahanan sosial keluarganya lemah, maka ketahanan sosial dalam keluarga tersebut masih belum bisa ditanggulangi permasalahannya sehingga menjadikan keluarga tersebut tidak harmonis dan sering terjadi kesalahpahaman serta banyak timbul saling terjadi kesalahan komunikasi antar anggota keluarganya (Sunarti, 2003). Selain itu, dikatakan tingkat ketahanan sosial dalam keluarga baik apabila keluarga mampu berorientasi pada nilai agama, komunikasi berlangsung efektif, komitmen keluarga tinggi (pembagian peran, dukungan untuk maju dan waktu kebersamaan keluarga, membina hubungan sosial dan mekanisme penanggulangan masalah (Puspitawati, 2013).

Tingkat ketahanan sosial keluarga yang sedang cenderung tidak berisiko untuk tidak kecanduan bermain game online pada siswa. Karena tingkat ketahanan sosial dirasa sangat penting bagi keberhasilan suatu keluarga. Tingkat ketahanan sosial keluarga kuat apabila dalam keluarga tersebut mampu menjaga komunikasi secara efektif dengan seluruh anggota keluarga, mampu membina hubungan sosial dengan baik antara anggota keluarga. Dan apabila tingkat ketahanan sosial keluarga lemah, dalam arti dalam keluarga tersebut kurang mampu komunikasi secara efektif dan kurang mampu membina hubungan baik dengan seluruh anggota keluarganya. Akibatnya anak tersebut lebih suka mencari kesenangan dan lebih gemar bermain game online.

Frekuensi bermain game online dalam seminggu maksudnya berapa kali dalam satu minggu para responden bermain game online. Berdasarkan hasil penelitian yang didapat, mayoritas frekuensi bermain responden dalam bermain game online adalah 1-2 kali per minggu, tersebut masuk dalam kategori tidak kecanduan sesuai dengan peneliti sebelumnya (Indahtiningrum, 2013), memaparkan bahwa pengkategorian frekuensi banyaknya bermain game online dikatakan anak tersebut gemar/kecanduan apabila penggunaannya antara $38 \mathrm{jam}$ atau 5-6 kali per minggu.

Mayoritas responden yang memilih waktu untuk bermain game online yaitu pada saat liburan sekolah karena pada saat liburan sekolah anak sekolah tersebut libur dari berbagai aktivitas belajar mengajar di sekolah dan mereka memiliki cukup banyak waktu untuk bermain tanpa adanya larangan dari orang tua. Namun, responden lainnya 
memilih waktu untuk bermain game online yaitu pada waktu pulang sekolah, malam hari, dan yang paling parah adalah bermain setiap hari, dikatakan anak tersebut gemar bermain game online dan nantinya bisa menjadi kecanduan yaitu apabila waktu bermain mereka dilakukan setiap hari Indahtiningrum, 2013).

Waktu yang digunakan dalam bermain game online tidak dapat dilakukan dalam waktu yang sebentar, karena pasti dirasa sangat kurang. Sehingga banyak dijumpai banyak kasus anak yang telah kecanduan game online, mereka rela menghabiskan kesehariannya hanya untuk bermain game online bahkan dalam Hanum (2014), menjelaskan bahwa ditemukan anak yang rela membolos sekolah dan tidak mengikuti kegiatan-kegiatan penting disekolah demi bermain game online, namun mereka juga takut apabila ketahuan oleh orang tuanya nanti akan dimarahi. Pada tahapan usia sekolah dasar biasanya seorang anak belum berani untuk membantah perintah orang tua atau membohongi orang tuanya karena takut nanti dihukum atau dimarahi. Sehingga diharapkan pada seluruh orang tua responden, pada tahap usia sekolah dasar peran orang tua harus senantiasa memantau, mengarahkan dan pengendali kegiatan sehari-hari anak-anaknya agar tidak menjadi kecanduan game online.

Mayoritas responden yang memilih durasi saat bermain game online yaitu responden dalam bermain game online adalah 1-2 jam per hari, termasuk dalam kategori tidak kecanduan sesuai dengan peneliti sebelumnya (Indahtiningrum, 2013) memaparkan bahwa pengkategorian lamanya bermain game online dikatakan anak tersebut kecanduan bermain game apabila penggunaannya antara lebih dari ( $>4-5$ jam per hari). Karena penggunaan pengkategorian per hari dapat membuat lebih jelas atau detail tentang durasi yang digunakan oleh responden.

Berdasarkan hasil penelitian yang dilakukan terdapat pengaruh antara ketahanan fisik kelurga terhadap kegemaran bermain game online yaitu $(\mathrm{p}=0,000 ; \mathrm{OR}=$ 0,49 ), maksudnya ketahanan fisik keluarga dalam kategori sedang berisiko 0,049 kali untuk gemar bermain game online dari pada ketahanan fisik keluarga dalam kategori kuat. Tingkat ketahanan keluarga responden dalam kategori sedang maksudnya yaitu tingkat ketahanan yang sedang berarti dalam keluarga tersebut cukup mampu untuk mencukupi segala kebutuhan baik sandang, pangan dan papan bagi seluruh keluarganya, cukup mampu mengatur ekonomi dan keuangan dalam keluarganya serta cukup mampu menciptakan SDM yang baik dan pintar. Hal ini didukung oleh penelitian Sunarti (2003), menjelaskan semakin kuat tingkat ketahanan fisik dalam suatu keluarga, maka semakin baik tingkat ketahanan keluarga.

Adanya kemampuan untuk mengatur, dan mengelola keuangan dalam keluarganya, maka akan berpengaruh nantinya pada pemberian uang saku pada anaknya dan memberikan segala fasilitas yang diinginkan oleh anggota keluarganya demi menyukupi dan menyenangkan hati anggota keluarganya, khususnya anak-anaknya. Pemberian uang saku yang berlebih pada anak yang masih duduk di sekolah dasar dan terlalu dimanjakan dengan segala fasilitas seperti halnya permainan, akan menjadikan menjadikan anak tersebut berpeluang penuh untuk sering bermain karena terfasilitasi dengan mudah. Kebanyakan anak-anak sering bermain game online di warung internet, apabila diberikan uang saku orangtuanya jika berlebih dan apabila dia sudah memiliki gadget sendiri dia akan menggunakan uangnya untuk membeli aplikasi game baru.

Tidak ada pengaruh antara tingkat ketahanan psikologis keluarga siswa terhadap kegemaran bermain game online pada siswa yaitu $(\mathrm{p}=0,216 ; \mathrm{OR}=0,523)$. Ketahanan psikologis keluarga dalam kategori sedang memiliki berisiko 0,523 kali untuk gemar bermain game online dari pada ketahanan psikologi keluarga dalam kategori kuat. Menurut Puspitawati (2013), menjelaskan ketahanan psikologis sangat penting bagi keberhasilan suatu keluarga karena didalam keluarga, dikatakan tingkat ketahanan psikologisnya kuat berarti dalam keluarga tersebut mampu menanggulangi permasalahan non fisik, mampu mengendalikan emosi secara positif, konsep positif dalam hal ini yaitu senantiasa peduli 
dan selalu mengajarkan nilai moral dan religius kepada seluruh anggota keluarganya. Namun, hasil penelitian didapatkan bahwa tingkat ketahanan psikologis keluarga responden dalam kategori sedang maksudnya dalam keluarga tersebut cukup mampu mengendalikan emosi pada saat keluarga mengalami permasalahan, cukup mampu mengajarkan nilai moral dan religius kepada seluruh anggota keluarga, bisa jadi anak tersebut akan memutuskan untuk mencari kesenangan dan hiburan diluar rumah.

Dalam penelitian ini didapatkan bahwa tingkat ketahanan psikologis keluarga responden tidak berpengaruh terhadap anak tersebut gemar bermain game online. Hal ini berbeda dengan hasil penelitian Sunarti (2003), yang menunjukkan ada pengaruh antara tingkat ketahanan keluarga terhadap kegemaran bermain game online. Hal ini karena adanya faktor lain yaitu keluarga tersebut mampu mengendalikan stressor. Tingkat ketahanan psikologis keluarga memang tidak berpengaruh terhadap kegemaran bermain game online pada siswa, namun bukan tidak mungkin dalam ketahanan psikologis yang kuat ataupun lemah berisiko untuk gemar bermain game online. Hanya saja memang perlu dipertimbangkan bahwa tingkat ketahanan psikologis keluarga turut berpengaruh pula dalam menentukan anak tersebut kecanduan atau tidak kecanduan siswa dalam bermain game.

Selanjutnya, berdasarkan hasil penelitian yang didapatkan menunjukkan bahwa terdapat pengaruh antara tingkat ketahan sosial keluarga siswa terhadap kegemaran bermain game online pada siswa yaitu $(\mathrm{p}=0,009 ; \mathrm{OR}=0,239)$, maksudnya ketahanan sosial keluarga dalam kategori sedang berisiko 0,239 kali untuk gemar bermain game online dari pada tingkat ketahanan sosial keluarga yang kuat. Menurut Pupitawati (2013), menjelaskan bahwa tingkat ketahanan sosial sangat penting bagi keberhasilan suatu keluarga karena didalam keluarga, dikatakan tingkat ketahanan sosial keluarga kuat yaitu apabila dalam keluarga tersebut mampu menjaga komunikasi secara efektif dengan seluruh anggota keluarga, mampu membina hubungan sosial dengan baik antara anggota keluarga serta mampu menghormati dan menghargai segala pendapat anggota keluarga. Namun, hasil penelitian didapatkan bahwa tingkat ketahanan sosial keluarga responden dalam kategori sedang, maksudnya dalam keluarga tersebut cukup mampu menjaga komunikasi secara efektif dan cukup mampu membina hubungan baik dengan seluruh anggota keluarganya.

Apabila dalam keluarga ditemukan ketahanan sosial keluarganya dalam kategori lemah, maka anggota keluarga akan mencari suatu kesenangan atau hiburan, pada umumnya anak-anak yang masih menginjak sekolah dasar, pada dasarnya mereka masih masih senang bermain bersama temantemannya. Karena mereka menganggap kurang merasa tidak diperdulikan, orangtua sangat sibuk sehingga jarang komunikasi dan bertemu, menyebabkan hubungan sosial antara anak dengan orangtua menjadi renggang. Akibatnya anak tersebut keluar untuk mencari kesenangan dengan bermain game.

\section{SIMPULAN}

Berdasarkan hasil penelitian yang telah diuraikan sebelumnya, maka dapat ditarik kesimpulan sebagai berikut: karakteristik siswa sebagian besar beralamat di Kelurahan Mulyorejo, dan sebagian besar umur siswa berumur 10 tahun, dan sebagian siswa berada di kelas IV B serta berdasarkan jumlah uang saku sebagian siswa yaitu Rp. 5000 per harinya.

Tingkat indikator ketahanan keluarga siswa yang meliputi ketahanan fisik, ketahanan psikologis dan ketahanan sosial termasuk dalam kategori ketahanan keluarga sedang. Sebagian besar tingkat indikator kegemaran bermain game online pada siswa kelas IV dan V di SD Hidayatul Ummah, Kelurahan Mulyorejo, sesuai hasil penelitian frekuensi bermain 1-2 kali per minggu, waktu bermain saat liburan sekolah dan durasi bermain game online yaitu 1-2 jam per hari. Ada pengaruh antara ketahanan fisik keluarga siswa terhadap kegemaran bermain game online pada siswa sekolah kelas IV dan V SD Hidayatul Ummah, Kelurahan Mulyorejo, Surabaya. 


\section{SARAN}

Berdasarkan hasil penelitian ini, ada beberapa saran yang ingin disampaikan oleh peneliti yaitu, pihak sekolah perlu adanya pemberian pendidikan kesehatan kepada seluruh siswanya tentang bahaya bermain game online, serta perlu pengawasan terhadap aktivitas anak sekolah dasar dengan mewajibkan siswa sekolah untuk mengikuti ektrakulikuler yang telah disediakan oleh pihak sekolah tersebut.

Diharapkan orang tua dapat menjalin komunikasi yang baik dengan anaknya, agar anak tersebut lebih terbuka dalam menyampaikan aspirasinya, dan diharapkan anak tersebut tidak merasa bosan dan kurang diperhatikan. Dan mengarahkan anaknya pada kegiatan yang positif dan bermanfaat, agar anak lebih kreatif dan berkembang, orang tua juga membatasi penggunaan waktu untuk bermain. Serta untuk lebih mengurangi jam layanan untuk bermain game online dengan cara memberikan salah satu kegiatan positif diluar rumah seperti halnya les musik dan olahraga.

\section{DAFTAR PUSTAKA}

Angela. Pengaruh Game Online Terhadap Motivasi Belajar Siswa SDN 015 Kelurahan Sidomulyo Kecamatan, Samarinda Ilir. eJournal Ilmu Komunikasi, 2013: 1 (2): hal. 532-544.

Biro Pusat Statistik. 2014. Data Presentasi Pengguna Game di Indonesia. Jakarta.

Handayani, S. 2011. Pengaruh Keluarga, Masyarakat Dan Pendidikan Terhadap Pencegahan Bahaya Narkoba Dikalangan Remaja. Tesis. Program Studi Pengkajian Ketahanan Nasional. Universitas Indonesia. Jakarta.

Hanum, K. 2014. Aktivitas Game Online Siswa SD (Kelas 3-6) Study Deskriptif Di Warnet Kelurahan Gunung Anyar Kota Surabaya. Skripsi Antropologi. Fakultas Ilmu Sosial Dan Ilmu Politik. Universitas Airlangga. Surabaya. 86 hal.
Imanuel, N. 2009. Gambaran Profil Keperibadian pada Remaja yang Kecanduan game online dan yang tidak kecanduan game online. Skripsi. Fakultas Psikologi. Universitas Indonesia. Depok.

Indahtiningrum, F. Hubungan Antara Kecanduan Video Game Online Dengan Stres Pada Mahasiswa Universitas Surabaya. Jurnal Ilmiah Mahasiswa Universitas Surabaya, 2013: Vol. 2 No. 1

Lumban, G.T, 2012. Hubungan Kecanduan Game Online Dengan Prestasi Akademik Mahasiswa DiFakultas TeknikUniversitas Indonesia. Fakultas Ilmu Keperawatan. Universitas Indonesia, Depok. Jakarta.

Notoadmodjo, S. 2005. Promosi Kesehatan Teori dan Aplikasi. Jakarta: PT Asdi Mahasatya.

Nikita. 2001. Bermain dan Permainan. Jakarta: PT. Sarana Kinasih Satya Sejati.

Puspitawati, H. 2013. Ketahanan dan Kesejahteraan Kelurga. Fakultas Ekologi Manusia Institut Pertanian Bogor: PT IPB Press. Bogor.

Rikiyanto. (2011). Pengaruh Game Online Terhadap Perlaku Remaja. Skripsi. Fakultas Ilmu Sosial dan Ilmu Politik, Universitas Andalas Press.

Sanditaria, W. 2008. Adiksi Bermain Game Online Pada Anak Usia SekolahDi Warung Internet Penyedia Game Online Jatinangor Sumedang. Jurnal Fakultas Ilmu Keperawatan Universitas Padjajaran: Bandung.

Soetjiningsih. 1998. Tumbuh Kembang Anak. Jakarta: EGC.

Sunarti, E. 2003. Perumusan Ukuran Ketahanan Keluarga. Media Gizi \& Keluarga, Juli 2003, 27 (1): 1-11.

Sunarti, E. 2005. Ketahanan Keluarga, Manajemen Stres, Serta Pemenuhan Fungsi Ekonomi dan Fungsi Sosialisasi Keluarga Korban Kerusuhan Aceh. Media Gizi \& Keluarga, Juli 2005, 29 (1): 41-49. 